\title{
PENGARUH INFLUENCER MARKETING DAN BRAND AWARENESS TERHADAP KEPUTUSAN PEMBELIAN STREET BOBA
}

\author{
Kelvin Yohanes ${ }^{1}$, Suharyati $^{2}$, Ediwarman $^{3}$ \\ ${ }^{1}$ Jurusan Manajemen, Universitas Pembangunan Nasional Veteran Jakarta \\ Email: kelvin.yohanes16@gmail.com \\ ${ }^{2}$ Jurusan manajemen, Universitas Pembangunan Nasional Veteran Jakarta \\ Email: yatididi03@gmail.com \\ ${ }^{3}$ Fakultas Ekonomi dan Bisnis, Universitas Pembangunan Nasional Veteran Jakarta \\ Email: ediwarman@upnvj.ac.id
}

\begin{abstract}
This study uses a descriptive quantitative study that aims to view and analyze the influence of influencer marketing and brand awareness on Street Boba's purchasing decisions. The sampling technique in this study used a nonprobability sampling technique, so that the entire population was sampled using the Lemeshow calculation formula and a sample of 100 respondents was obtained. Smart PLS 3.0 software and Microsoft Office Excel are used in hypothesis testing. The examiners' results are: (1) There is a significant influence of influencer marketing on purchasing decisions, (2) There is a significant influence of brand awareness on purchasing decisions.
\end{abstract}

Keywords: Influencer Marketing, Brand Awareness, Purchase Decisions

\begin{abstract}
ABSTRAK
Penelitian ini merupakan penelitian deskriptif kuantitatif yang digunakan untuk menganalisis dan mengetahui pengaruh influencer marketing dan brand awareness terhadap keputusan pembelian Street Boba. Penelitian ini menggunakan sampel klien Street Boba di Jakarta Selatan. Teknik pengambilan sampel dalam penelitian ini menggunakan teknik non-probability sampling, sehingga rumus perhitungan Lemeshow dipilih dengan menggunakan seluruh populasi dan diperoleh sampel sebanyak 100 responden. Pengujian hipotesis menggunakan software SmartPLS 3.0 dan Microsoft Office Excel. Hasil pengujian adalah (1) influencer marketing berpengaruh signifikan terhadap keputusan pembelian dan (2) brand awareness berpengaruh signifikan terhadap keputusan pembelian.
\end{abstract}

Kata Kunci: Influencer Marketing, Brand Awareness, Keputusan Pembelian, Street Boba

\section{PENDAHULUAN}

Latar Belakang

Pembelian produk bukan hanya untuk memuaskan keinginan, tetapi untuk memenuhi kebutuhan. Keputusan pembelian konsumen sangat penting bagi perusahaan. Jika konsumen membeli lebih banyak produk dan jasa, maka akan ada kemajuan komersial, karena dapat meningkatkan profitabilitas perusahaan. Keputusan pembelian tidak hanya menghasilkan keuntungan bagi perusahaan, tetapi semakin banyak konsumen membeli maka masyarakat luas akan mengetahui produk tersebut. Agar konsumen dapat membeli produk yang dihasilkan, perusahaan dapat mengambil beberapa cara, seperti menggunakan strategi Influencer marketing dan meningkatkan Brand Awareness pada usaha nya

Strategi yang dapat dilakukan oleh perusahaan untuk beradaptasi di zaman yang modern ini salah satunya dengan menerapkan digital marketing. Data menunjukkan bahwa penguna internet mencapai $64 \%$ dari total penduduk Indonesia atau sekitar 175,4 juta. maka dari itu digital marketing berpotensi untuk digunakan dalam memasarkan dan mempromsikan produk atau jasa di Indonesia. 


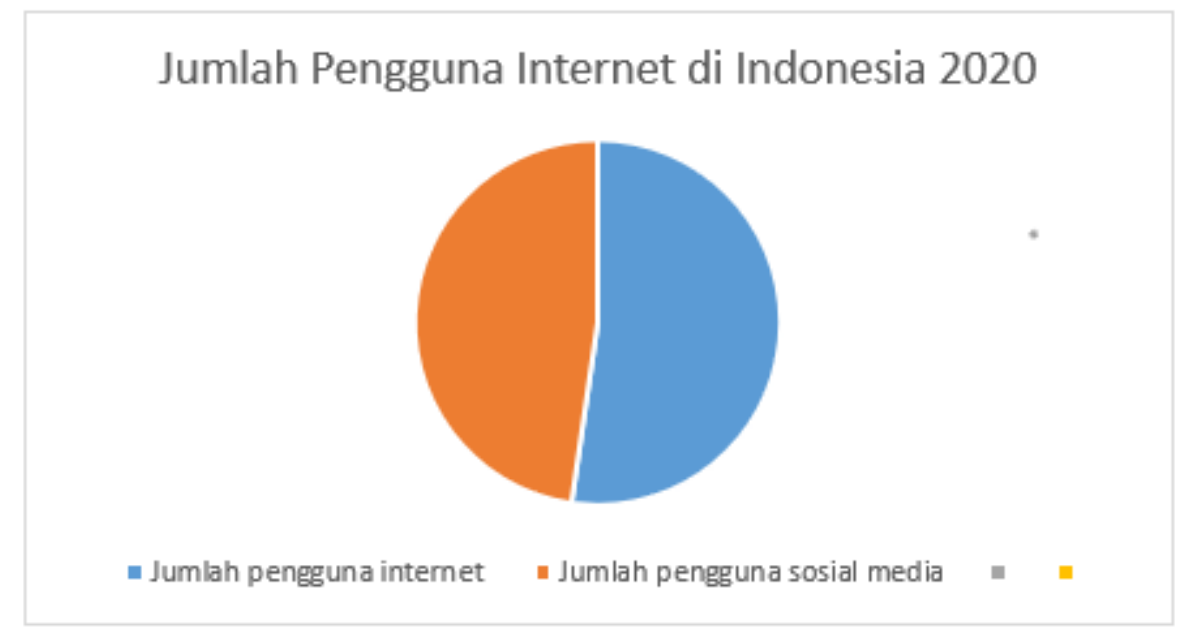

Gambar 1. Data Pengguna Internet di Indonesia

Sumber : We are social, 2020

Di era digital sekarang ini teknologi digital dapat di manfaatkan dalam melakukan strategi marketing dengan cara memanfaatkan sosial media yang bertujuan untuk mempermudah konsumen dalam melakukan pembelian serta meningkatkan kepercayaan konsumen supaya tercapainya keputusan pembelian salah satu teknik pemasaran di era modern ini yaitu influencer marketing hal ini merupakan salah satu faktor meningkatnya brand awareness diharapkan berdampak terhadap keputusaan pembeliaan.

"Influencer marketing menjadi salah satu strategi yang berpengaruh dalam menandatangkan calon konsumen, karena seorang influencer dapat meningkatkan citra merek dan kesadaran merek yang berpeluang terciptanya keputusan pembelian pada konsumen (Hariyanti \& Wirapraja, 2018)".

Sedangkan "brand awareness atau kesadaran merek adalah kemampuan diri seseorang yang merupakan calon pembeli atau potential buyer untuk mengenali atau menyebutkan kembali suatu merek merupakan bagian dari suatu kategori dari produk tertentu (Rangkuti, 2009)". Menurut (Priansa, 2017) merek terdiri dari atas empat tingkatan berbeda yang menjadi yaitu kesadaran yang rendah akan merek (unware brand), mengenali suatu merek (brand recognition), mengingat merek (brand recall), dan puncak pikiran (top of mind).

Pada era saat ini banyak sekalia usaha yang menerapkan Teknik Influencer Marketing salah satunya yaitu usaha dibidang minuman salah satunya jenis minuman Boba. Peluang usaha minuman sangat besar di Indonesia mengingat Indonesia memiliki iklim yang tropis, dari tahun ketahun berbagai jenis varian minuman segar di indonesia sangat beragam seperti thai tea, dalgona coffe, dan bubble tea atau boba yang akan peneliti bahas dalam penelitian ini.

\begin{tabular}{ccc}
\hline Merek & TBI & TOP \\
\hline Chatime & $56,0 \%$ & TOP \\
\hline Hop-Hop & $12,5 \%$ & TOP \\
\hline Lup-Lup & $11,9 \%$ & \\
\hline Chill Bubble Tea & $4,5 \%$ & \\
\hline Quickly & $3,1 \%$ & \\
\hline
\end{tabular}

Sumber : Topbrand-award.com 
Data diatas menunjukan data dari Top Brand Index (TBI) Bubble tea di Indonesia pada tahun 2020. Data tersebut dujelaskan bahwa Chatime menjadi top brand bubble tea di Indonesia dengan persentase 56,0 \% disusul oleh Hop-Hop dan Lup-Lup yang bersaing ketat dan Chill Bubble Tea dan Quickly di urutan paling bawah.

Street Boba memulai usahanya dengan membuka gerai pertamanya di Kawasan ampera Jakarta selatan, untuk mempromosikan produknya Street Boba melakukannya menggunakan cara yang cukup unik yaitu dengan cara bekerja sama dengan influencer baik dengan cara endorsemen dan kolaborasi ataupun. franchaise.(marketing.co.id).

Street Boba merupakan salah satu karya Nikmat Group yang sukses di bidang Makanan dan Minuman setelah Kopi Lain Hati, dengan meluncurkan minuman boba kekinian dengan nama Street Boba ini menarik perhatian publik. Nama Street Boba diambil dari konsep yang sengaja diterapkan karena tempat ini diadaptasi dari sebuah toko makanan jalanan di Shibuya, Jepang. Street Boba pertama kali membuka restoran baru di Kawasan Ampera Jakarta Selatan dan mampu memasarkan minuman jenis boba dengan harga yang relatif lebih terjangkau namun tetap berkualitas. Berbeda dengan brand boba lainnya yang lebih banyak berada di pusat perbelanjaan. sedangkan Street Boba sendiri memasarkan produknya dengan gerai yang berlokasi di pinggir jalan. Saat ini street boba memilki 100 gerai yang tersebar di indonesia dan menargetkan hingga 200 gerai.

Berdasarkan fenomena yang terjadi, maka peneliti ingin membahas dan memperdalam mengenai beberapa permasalahan yang melatarbelakangi penelitian ini. peneliti ingin melakukan penelitian yang berjudul pengaruh Influencer Marketing dan Brand Awaraness Terhadap Keputusan Pembelian Street Boba.

\section{Rumusan Masalah}

Berdasarkan latar belakang maka dapat dirumuskan masalah seperti berikut:

1. Apakah influencer marketing berpengaruh terhadap keputusan pembelian Street Boba?

2. Apakah brand awareness berpengaruh terhadap keputusan pembelian Street Boba?

\section{METODE PENELITIAN}

\section{Definisi Operasional}

Keputusan Pembelian

Menurut (firmansyah, $2017 \mathrm{hlm}$. 24) "keputusan pembelian merupakan proses pencarian informasi dan pengenalan produk atau jasa yang dibutuhkan oleh konsumen". Menurut engel dalam (Firmansyah, 2017) "Pengambilan keputusan membeli dipacu dengan tindakan konsisten dari konsumen yang dapat dengan cepat dilakukan untuk memenuhi kebutuhan".

Influencer Marketing

Influencer marketing merupakan strategi pemasaran dengan cara menggunakan influencer atau seseorang yang terkenal untuk mempengaruhi konsumen untuk meningkatkan kesadaran pada merek dan perilaku pada konsumen (Brown \& Fiorella, 2013)

Brand Awareness

"Menurut (Aaker, 2013) brand awareness dapat di kategorikan sebagai tingkat kesanggupan konsumen untuk mengenali produk atau merek tertentu. brand awareness dapat diartikan sebagai kesanggupan seorang calon pembeli untuk mengenali atau mengingat kembali suatu merek sebagai bagian dari suatu kategori produk tertentu yang dapat membentuk perilaku konsumen".

Pengukuran Variabel

Penelitian ini menggunakan skala ordinal untuk jenis skala pengukurannya dengan bentuk skala likert. Untuk itu penelitian ini menggunakan skala pengukuran variabel sebagai berikut:

Keputusan Pembelian (Y) 
Pada penelitian ini, keputusan pembelian akan diukur dengan jawaban dari responden berdasarkan indikator yang dikemukakan oleh Kotler dan keller dalam (Tjiptono, 2012) yaitu, pilihan produk, merek, disitributor, waktu pemnbelian dan jumlah pembelian.

Influencer Marketing (X1)

Pada penelitian ini, Influencer Marketing akan diukur melalui jawaban yang diperoleh dari responden berdasarkan indikator yang dikemukakan oleh Hovland dalam (Smuda, 2018) yaitu, trustworthiness, expertise, attractiveness.

Brand awareness (X2)

pada penelitian ini, Brand awareness diukur melalui jawaban yang diperoleh dari responden berdasarkan indikator yang dikemukan oleh (Kotler \& Keller, 2016) yaitu, recall, recognition, dan purchase.

\section{Populasi dan Sampel \\ Populasi}

Populasi "menurut sugiyono dalam (Nurdin \& Hartati, 2019) merupakan wilayah generalisasi yang terdiri dari obyek atu subjek yang mempunyai kualitas dan karakterisitik tertentu yang diterapkan oleh peneliti untuk di pelajari dan di tarik kesimpulannya". "Menurut (Siyoto \& Ali, 2015) Populasi bukan hanya sekedar jumlah yang ada pada objek atau subyek yang dipelajari akan tetapi dapat meliputi karakteristik dan sifat yang dimiliki obyek dan subyek tersebut". Target populasi dari penelitian yaitu konsumen Street Boba yang berdomisili di Jakarta Selatan.

\section{Sampel}

"Sampel adalah sebagian dari jumlah dan karakteristik yang dimiliki oleh populasi ataupun bagian kecil dari anggota populasi yang diambil menurut prosedur tertentu sehingga dapat mewakili populasinya (Siyoto \& Ali, 2015)". Sampling dapat mempermudah peneliti di karenakan dapat menghemat waktu dan biaya penelitian.

Pada penelitian ini data diambil data diambil berdasarkan data dari para responden yang mana data yang diperoleh merupakan data dari sampel yang mewakili seluruh populasinya. maka, supaya mewakili populasi atau representative Perhitungan sampel untuk penelitian ini yaitu dengan menggunakan Lemeshow.

Dengan cara sebagaai beerikut:

$$
\begin{aligned}
& n=\frac{Z^{2} \cdot P(1-P)}{d^{2}} \\
& \text { Diketahui : } \\
& \mathrm{n}=\text { Banyaknya Sampel } \\
& \mathrm{Z}=\text { Trust Value 95\% }(1,96) \\
& \mathrm{P}=\text { Max Estimation }(0.5) \\
& \mathrm{d}=\text { Tingkat Kesalahan }(5 \%) \\
& \text { Jawab : } \\
& n=\frac{1.96^{2} \cdot 0.5(1-0.5)}{0.05^{2}} \\
& \mathbf{n}=\mathbf{9 6 . 0 4}
\end{aligned}
$$

Sampel yang diambil dari 100 partisipan di Jakarta Selatan, setelah itu dibulatkan dengan perhitungan menggunakan Lemeshow. 


\section{Teknik Pengumpulan Data}

\section{Jenis data}

Jakarta, 21 Oktober 2021

Jenis data yang digunakan pada penelitian ini adalah kuantitatif. "Data kuantitatif adalah data yang telah diolah atau dianalisis dengan menggunakan teknik komputasi matematis atau statistik.o (Siyoto \& Ali, 2015)".

\section{Sumber Data}

Penelitian ini menggunakan tangan pertama sebagai sumber, sumber data tangan pertama diambil dari hasil penelitian di bidang ini. menyebar kuisioner kepada konsumen Street Boba di Jakarta.

\section{Pengumpulan Data}

Metode yang dilakukan untuk mengumpulkan data dilakukan dengan menggunakan kuesioner yang akan disebarkan kepada konsumen street boba di wilayah Jakarta. "Kuesioner adalah metode pengumpulan data dengan cara mengajukan pertanyaan secara sistematis kepada responden (Rahardjo \& Gudnanto, 2013)". Kuisoner akan disebarkan dengan berbasih media digital yaitu berupa google form.

Skala yang akan digunakan yaitu skala likert. "Skala likert digunakan untuk mengukur pendapat dan persepsi seseorang terhadap fenomena sosial (Ansori, 2020)". Adapun skala likert pada penelitian ini diberikan kepada masing-masing indikator di setiap variabel

\section{Teknik Analasis Data}

\section{Teknik Analisis Deskriptif}

"Analisis deskriptif merupakan cara mendeskripsikan data yang telah terkumpul dalam suatu penelitian (Ferdinand,2014)" . penelitian analisis Deskriptif yang digunakan adalah Analisa indeks yang didapat dari pernyataan dari kusioner table interprestasi nilai sebgai berikut:

\begin{tabular}{cc}
\hline Nilai Indeks & Interpretasi \\
\hline $10,00-40,00$ & Rendah \\
\hline $40,01-70,00$ & Sedang \\
\hline $70,01-100,0$ & Tinggi \\
\hline
\end{tabular}

Tabel interpretasi nilai indeks responden diatas dapat diimplementasikan bahwa nilai 10.00 40,00 diinterpretasikan nilai rendah, kemudian nilai 40,01 - 70,00 menginterpretasikan nilai sedang, terakhir nilai 70,01 - 100,00 menginterpretasikan nilai tinggi.

\section{Teknik Analisis Data Inferensial}

Analisa inferensial adalah Langkah yang dipakai pada analisis data serta hasil yang diperoleh akan disimpulkan melalui sampel yang diambil (Kusumastuti et al., 2020). Analisis inferensiaal yang dilakukan pada penelitian ini didapatkan dari hasil output partial least square (PLS).

Menurut (Noor, 2014) terdapat langkah-langkah dalam mengunakan SmartPLS, yaitu sebagai berikut:

1. Merancang structural model (inner model)

2. Merancang measurement model (outer model)

3. Mengkonstruksi diagram jalur

4. Konversi diagram jalur ke sistem persamaan

5. Parameter estimasi

6. Goodness of Fit 


\section{Uji Validitas}

"Uji validitas adalah ketepatan suatu alat ukur dalam menjalankan fungsi pengukurannya. Instrument dikatakan layak jika dapat mengungkap data dari suatu variabel secara tepat (Yusup,2018)". Validitas menunjukan ketepatan alat ukur dalam mengukur suatu masalah yang akan di ukur (Wahyudi, 2020).

Berdasarkan analisis serta uji validitas kepada model pengukuran, indikator dapat dinyatakan valid atau tidak dengan cara melihat melalui convergent valiidity, discriminant valiidity, dan AVE (average variance extracted).

\section{Uji $\mathbf{R}^{2}$ (Koefisien Determinasi)}

Uji R-square digunakan untuk mendapatkan kesesuain hubungan antar variabel independent dan dependen. Koefisien determinasi menjelaskan seberapa besar perubahan dalam satu variabel dapat dijelaskan oleh perubahan atau perubahan variabel lainnya. "Jika hasilnya dekat 0 , berarti kemampuan variabel bebas untuk menjelaskan perubahan variabel sangat terbatas,Namun, ketika hasilnya mendekati 1,variabel independen menyediakan hampir semua informasi yang diperlukan untuk memprediksi perubahan variabel dependen (Ghozali, 2013)".

\section{Uji t (Uji Parsial)}

Uji hipotesis pada penelitian ini dengan uji parsial (pembuktian). yaitu salah satu uji statistik untuk menguji keaslian hipotesis nol, yang menunjukkan tidak ada perbedaan antara dua sampel acak yang signifikan dari populasi yang sama (Sudjono, 2010). Pengujian hipotesis dalam penelitian ini diambil dari output PLS khususnya pada tabel uji-t.

\section{HASIL DAN PEMBAHASAN}

\section{Uji Validitas}

\section{Uji Validitas Konvergen}

Nilai load factor dari masing-masing indikator pada output menggunakan software SmartPLS 3.0 diperoleh masing-masing

Tabel Nilai Outer Loadings

\begin{tabular}{cccc}
\hline \multicolumn{5}{c}{ Brand Awareness (X2) } & $\begin{array}{c}\text { Influencer Marketing } \\
\text { (X1) }\end{array}$ & $\begin{array}{c}\text { Keputusan Pembelian } \\
\text { (Y) }\end{array}$ \\
\hline B1 & 0,812 & \\
\hline B2 & 0,740 & & \\
\hline B3 & 0,800 & & \\
\hline B4 & 0,752 & \\
\hline B5 & 0,835 & \\
\hline B6 & 0,819 & \\
\hline B7 & 0,851 & & \\
\hline B8 & 0,871 & 0,789 & \\
\hline I2 & & 0,883 & 0,879 \\
\hline I3 & 0,820 & $-0,111$ \\
\hline I4 & 0,871 & 0,835 \\
\hline I5 & & 0,770 \\
\hline I6 & & 0,840 \\
\hline KP1 & & \\
\hline KP10 & & \\
\hline KP2 & & \\
\hline KP3 & & \\
\hline KP4 & & \\
\hline
\end{tabular}




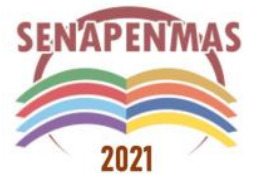

Seminar Nasional Hasil Penelitian dan Pengabdian Kepada Masyarakat 2021 Pengembangan Ekonomi Bangsa Melalui Inovasi Digital Hasil Penelitian dan Pengabdian Kepada Masyarakat Jakarta, 21 Oktober 2021

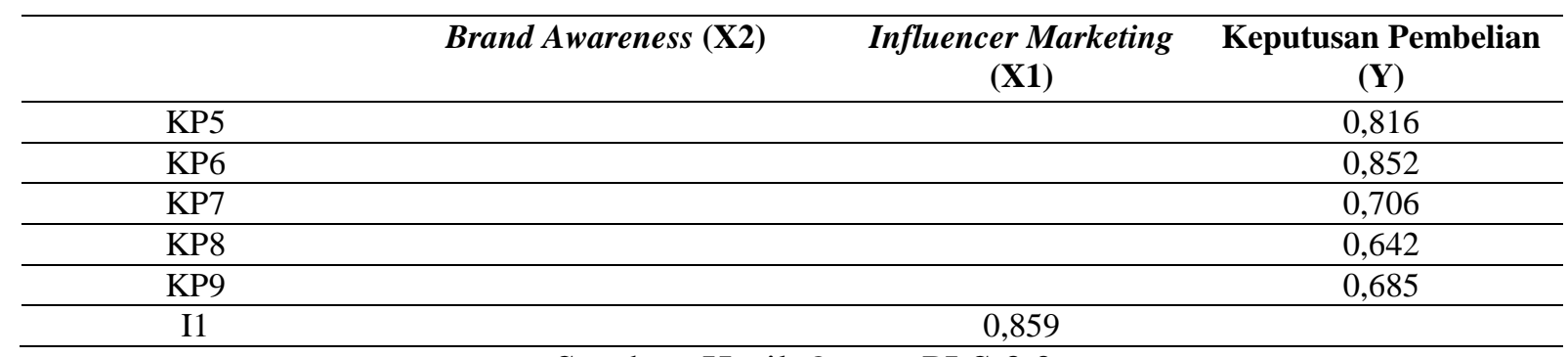

Sumber: Hasil Output PLS 3.0

Berdasarkan nilai output dari outer loading menggunakan software SmartPLS 3.0 menunjukkan adanya indikator yang harus didrop atau dibuang dari model yaitu KP10 karena menghasilkan angka dibawah 0,5 dan tidak signifikan. Model direestimasi dengan membuang indikator yang tidak memenuhi syarat dengan melihat hasil output pada tabel berikut ini.

Tabel Nilai Outer Loading (Reestimasi ke-1)

\begin{tabular}{|c|c|c|c|}
\hline & Brand Awareness (X2) & $\begin{array}{c}\text { Influencer Marketing } \\
\text { (X1) }\end{array}$ & $\begin{array}{c}\text { Keputusan Pembelian } \\
\text { (Y) }\end{array}$ \\
\hline B1 & 0,812 & & \\
\hline B2 & 0,740 & & \\
\hline B3 & 0,800 & & \\
\hline B4 & 0,752 & & \\
\hline B5 & 0,835 & & \\
\hline B6 & 0,819 & & \\
\hline B7 & 0,851 & & \\
\hline B8 & 0,871 & & \\
\hline $\mathrm{I} 2$ & & 0,789 & \\
\hline I3 & & 0,883 & \\
\hline I4 & & 0,879 & \\
\hline I5 & & 0,820 & \\
\hline I6 & & 0,871 & \\
\hline KP1 & & & 0,779 \\
\hline KP2 & & & 0,835 \\
\hline KP3 & & & 0,770 \\
\hline KP4 & & & 0,840 \\
\hline KP5 & & & 0,816 \\
\hline KP6 & & & 0,852 \\
\hline KP7 & & & 0,706 \\
\hline KP8 & & & 0,642 \\
\hline KP9 & & & 0,685 \\
\hline I1 & & 0,859 & \\
\hline
\end{tabular}

Sumber: Hasil Output PLS

Berikut hasil Outer Loading pada Software SmartPLS 3.0 setelah reestimasi ke-1, seluruh indikator pertanyaan telah menunjukkan angka di atas 0,5 sehingga pada seluruh indikator dapat dinyatakan valid dan telah memunuhi convergemt validity.

\section{Uji Validitas Diskriminan}




\begin{tabular}{cccc}
\hline & $\begin{array}{c}\text { Brand } \\
\text { Awareness } \\
(\mathbf{X} 2)\end{array}$ & $\begin{array}{c}\text { Influencer } \\
\text { Marketing } \\
(\mathbf{X 2})\end{array}$ & $\begin{array}{c}\text { Keputusan } \\
\text { Pembelian } \\
(\mathbf{Y})\end{array}$ \\
\hline Brand Awareness $(\mathrm{X} 2)$ & 0,811 & & \\
\hline Influencer Marketing (X1) & 0,839 & 0,851 & 0,773 \\
\hline Keputusan Pembelian (Y) & 0,821 & 0,842 & \\
\hline & Sumber: Hasil Output PLS
\end{tabular}

Tabel di atas menunjukan yaitu dalam konstruksi setiap variabel validitas judgement yang dilakukan oleh tabel Fornel-Laccker Criteriium memiliki nilai lebih besar dari 0,6. Nilai Brand Awareness (X2) sebesar 0,811, nilai Influencer Marketing (X1) sebesar 0,851, dan nilai Keputusan Pembelian (Y) sebesar 0,773. Dengan demikian, disimpulkan bahwa konstruksi Brand Awareness, Influencer Marketing, Keputusan Pembelian dianggap valid.

Cara lain untuk memeriksa validitas diskriminasi adalah dengan memeriksa akar kuadrat dari nilai rata-rata ekstraksi varians (AVE). Nilai disarankan lebih besar dari 0,5.

Tabel Nilai Average Variance Extracted (AVE)

\begin{tabular}{ll}
\hline Keterangan & Average Variance Extracted (AVE) \\
\hline Brand Awareness (X2) & 0,658 \\
\hline Influencer Marketing (X1) & 0,724 \\
\hline Keputusan Pembelian (Y) & 0,597 \\
\hline \multicolumn{2}{r}{ Sumber: Hasil Output PLS }
\end{tabular}

Tabel tersebut menunjukkan nilai AVE untuk setiap konstruk dalam model penelitian lebih besar dari 0,5. Nilai AVE terendah pada tabel adalah 0,597 untuk konstruk keputusan pembelian dan nilai AVE tertinggi adalah 0,724 untuk konstruk influencer marketing. Dari sini dapat disimpulkan bahwa brand awareness, influencer marketing, keputusan pembelian adalah valid.

\section{Uji Reliabilitas}

Berikut keandalan komposit dan nilai alpha cronbach masing-masing variabel konstruksi dengan hasil output perangkat lunak SmartPLS 3.0

Tabel Nilai Composite Reliability

\begin{tabular}{lc}
\hline \multicolumn{1}{c}{ Keterangan } & Composite Reliability \\
\hline Brand Awareness (X2) & 0,939 \\
\hline Influencer Marketing (X1) & 0,940 \\
\hline Keputusan Pembelian (Y) & 0,930 \\
\hline
\end{tabular}

Sumber: Hasil Output SmartPLS 3.0

Hasil table diatas menunjelaskan bahwa nilai reliabilitas komprehensif seluruh struktur di atas 0,7, yang dapat dinyatakan semua struktur model yang di estimasi mencapai standar dengan nilai tertinggi dimiliki oleh variable Influencer Marketing sebesar 0,940. 


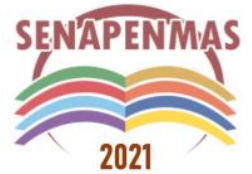

Seminar Nasional Hasil Penelitian dan Pengabdian Kepada Masyarakat 2021 Pengembangan Ekonomi Bangsa Melalui Inovasi Digital Hasil Penelitian dan Pengabdian Kepada Masyarakat Jakarta, 21 Oktober 2021

Dengan metode Cronbach's Alpha di mana output yang dihasilkan dapat memperkuat Uji reliabilitas seperti berikut:

\begin{tabular}{|c|c|}
\hline Keterangan & Cronbach's Alpha \\
\hline Brand Awareness (X2) & 0,925 \\
\hline Influencer Marketing (X1) & 0,923 \\
\hline Keputusan Pembelian (Y) & 0,916 \\
\hline
\end{tabular}

Nilai yang direkomendasikan lebih tinggi dari pada 0,6 akan dianggap sebagai konstruksi model penelitian yang andal atau andal, dan dapat disimpulkan bahwa semua variabel dinyatakan reliabel untuk setiap indikator.

\section{Uji Hipotesis}

\section{Uji t-statistik}

Metode analisis yang digunakan menggunakan metode Bootstrapping melalui software SmartPLS 3.0 untuk uji statistik T. Diketahui bahwa t tabel $=1.98472$ yang diperoleh dari rumus $\mathrm{df}=\mathrm{N}-\mathrm{K}$ atau $\mathrm{df}=100-3=97$, hal ini berkaitan dengan tingkat kepercayaan 5\% atau 0,05.

Tabel Hasil Uji t-Statistik

\begin{tabular}{lccccc}
\hline & $\begin{array}{c}\text { Original } \\
\text { Sampel } \\
(\boldsymbol{O})\end{array}$ & $\begin{array}{c}\text { Sample } \\
\text { Mean } \\
(\boldsymbol{M})\end{array}$ & $\begin{array}{c}\text { Standard } \\
\text { Deviation }\end{array}$ & $\begin{array}{c}\text { T Statistics } \\
(\text { OO/STDEV) }\end{array}$ & $\begin{array}{c}\boldsymbol{P} \\
\text { Values }\end{array}$ \\
\hline $\begin{array}{l}\text { Influencer Marketing (X1) -> Keputusan } \\
\text { Pembelian (Y) }\end{array}$ & 0,518 & 0,514 & 0,099 & 5,222 & 0,000 \\
\hline $\begin{array}{l}\text { Brand Awareness (X2) -> Keputusan } \\
\text { Pembelian (Y) }\end{array}$ & 0,387 & 0,395 & 0,104 & 3,715 & 0,000 \\
\hline
\end{tabular}

Sumber: Hasil Output PLS

Hasil SmartPLS edisi 3.0 pada Tabel menunjukkan bahwa hasil pengujian variabel Influencer Marketing (X1) dalam keputusan pembelian memiliki Thitung sebesar 5,222 > Ttabel 1,98472 dan signifikansi sebesar $0,000<0,05$ ini mengukuhkan, yaitu influencer marketing berpengaruh positif terhadap keputusan pembelian .

Kemudian untuk hasil SmartPLS pada Tabel diatas terlihat nilai hasil uji variabel brand awareness (X2) dalam keputusan pembelian memiliki hasil Thitung 3,71 > Ttabel 1,98472 dan nilai signifikansi $0,000<0,05$ ini ditunjukan kesadaran merek berpengaruh positif terhadap keputusan pembelian. Berikut bentuk model penelitian dengan model internal dapat digambarkan : 


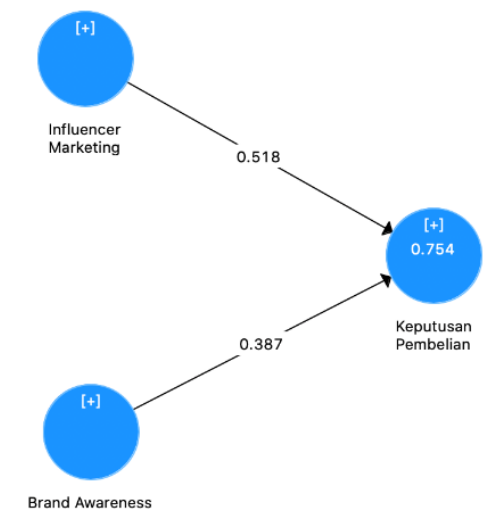

Sumber: Hasil Output PLS

\section{$\mathbf{U j i} \mathbf{R}^{2}$}

Berikut Nilai dari $R$ Square ditujukan sebagai variabel dependen atau variabel terikat. Hasil yang diperoleh melalui output SmartPLS 3.0

Tabel Nilai $R$ Square dan $R$ Square Adjusted

\begin{tabular}{lcc}
\hline & $R$ Square & $\boldsymbol{R}$ Square Adjusted \\
\hline Keputusan Pembelian (Y) & 0,754 & 0,749 \\
\hline
\end{tabular}

Sumber: Hasil Output PLS

pada hasil di atas terlihat bahwa keputusan pembelian R-squared (R2) sebesar 0,754, yang menunjukkan bahwa Influencer Marketing dan Brand Awareness mempengaruhi sebesar 0,754 sekitar 75,4\% terhadap keputusan pembelian, dan varibabel lain sisanya mempengaruhi sebesar 24,6\%. Sedangkan nilai Adjusted R-squared keputusan pembelian variabel Y sebesar 0,749 sekitar 74,9\% dan terdapat $25,1 \%$ dipengaruhi oleh variabel diluar penelitian ini .

\section{Pengaruh Influencer Marketing Terhadap Keputusan Pembelian}

Penelitian ini menunjukan bahwa variabel influencer marketing mempengaruhi positif signifikan terhadap keputusan pembelian, dengan bukti yang diarahkan pada nilai koefisien jalur sebesar 0,518 dan uji t menunjukkan bahwa Nilai Thitung sebesar 5,222 > Ttabel 1,98472 dan nilai signifikan sebesar $0,000<0,05$.

Hal ini menunjukkan adanya ketertarikan pelanggan yang disebabkan promosi yang dilakukan oleh influencer tersebut. Maka dari itu, influencer marketing dikatakan mempengaruhi keputusan pembelian Street Boba. Sejalan dnegan hasil penelitian sebelumnya dari "Tee et al (2020), Amalia \& Sagita (2019), Wiliana et al. (2020), Hernanda et al. (2019), Dewa (2018), dan Mulyanto (2019) menjelaskan bahwa Influencer Marketing dapat mempengaruhi Keputusan Pembelian".

\section{Pengaruh Brand Awareness Terhadap Keputusan Pembelian}

Berdasarkan hasil dalam penelitian ini, dapat ditunjukkan bahwa variabel Brand Awareness memilki nilai koefisien jalur sebesar 0,387, yang artinya memengaruhi secara signifikan terhadap 
keputusan pembelian dan uji t statistik memiliki thitung. sampel sebesar 3,715> Ttabel sebesar 1,98472 dan nilai signifikansi sebesar $0,000<0,05$.

Dalam penelitian ini mempengaruhi keputusan pembelian Street Boba sesuai dengan hasil penelitian terdahulu dari "Deodata \& Soamole (2019), Ameliawaty \& Halilah (2018), Rantau (2013), Krisnawati (2016), dan Tee et al (2020) mengatakan bahwa Brand Awareness memiliki pengaruh terhadap Keputusan Pembelian".

\section{KESIMPULAN DAN SARAN}

\section{Kesimpulan}

Berdasarkan hasil sekumpulan penelitian dan uji hipotesis yang digunakan melalui analisa PLS (Partial Least Square) dan SmartPLS Pengaruh Influencer Marketing Dan Brand Awareness Terhadap Keputusan Pembelian Street Boba dapat disimpulkan sebagai berikut:

1. Influencer marketing berpengaruh positif dan signifikan, hal ini membuktikan bahwa teknik penggunaan influencer untuk mempromosikan produk Street Boba dapat mempengaruhi seseorang terhadap pembelian produk Street Boba.

2. Brand Awareness memiliki pengaruh positif dan signifikan terhadap keputusan pembelian, yaitu tingkat Brand Awareness masyarakat dapat mempengaruhi keputusan pembelian pada Street Boba.

\section{Saran}

Berdasarkan hasil penjelasan kesimpulan diatas, peneliti memberi masukan kepada peneliti yang lain disarankan dapat menggunakan objek penelitian yang lain serta menambah variabel bebas diluar variabel dalam penelitian ini, mengingat masih banyaknya variabel bebas diluar variabel pada penelitian ini. Beberapa Ada variabel yang dapat mempengaruhi keputusan pembelian dan disarankan untuk peneliti menggunakan data untuk memperbanyak sampel dan responden sehingga hasil investigasi memungkinkan di generalisasi.

Kemudian disarankan kepada Street Boba untuk memaksimalkan Teknik pemasaran dengan menggunakan Influencer, seperti menambahkan frekuensi dari Influencer, memperbanyak melakukan kolaborasi dengan beberapa Influencer lainnya, dan berkerjasama dengan beberapa Influencer ternama yang memiliki jumlah pengikut yang banyak contohnya seperti Rachel Venya. Selanjutnya kepada Street Boba agar dapat meningkatkan Brand Awareness nya untuk menigkatkan penjualan dan mengembangkan usahanya dengan melakukan beberapa hal seperti lebih aktif melakukan promosi dan kegiatan lainnya di media sosial, melakukan kegiatan giveaway, dan menggunakan tenaga Influencer

\section{Ucapan Terima Kasih (Acknowledgement)}

Puji dan syukur penulis panjatkan kepada Tuhan Yesus dengan segala berkat dan kasihnya sehingga hasil penelitian ini telah berhasil diselesaikan dengan judul "Pengaruh Influencer Marketing Dan Brand Awareness Terhadap Keputusan Pembelian Street Boba" Pada kesempatan kali ini penulis menyampaikan ucapan terima kasih kepada seluruh pihak yang membantu. 
Seminar Nasional Hasil Penelitian dan Pengabdian Kepada Masyarakat 2021

Pengembangan Ekonomi Bangsa Melalui Inovasi Digital Hasil Penelitian dan

Pengabdian Kepada Masyarakat

Jakarta, 21 Oktober 2021

\section{REFERENSI}

Aaker, D. (2013). Advertising's Role In Building Strong Brands.

Ansori, M. (2020). Metode Penelitian Kuantitatif Edisi 2 - Google Books. https://www.google.co.id/books/edition/Metode_Penelitian_Kuantitatif_Edisi_2/rKbJD wAAQBAJ?hl=id\&gbpv=1\&dq=pengertian+skala+likert\&printsec=frontcover

Brown, D., \& Fiorella, S. (2013). Influence Marketing - Google Books. 2013. https://www.google.co.id/books/edition/Influence_Marketing/xRt$\mathrm{kC6}$ o34C?hl=id\&gbpv=1\&dq=influencer+marketing\&pg=PT48\&printsec=frontcover

Ghozali, I. (2013). Aplikasi Analisis Multivariate dengan Program IBM SPSS 21 Update PLS Regresi. Badan Penerbit Universitas Diponegoro.

Hariyanti, N. T., \& Wirapraja, A. (2018). Pengaruh Influencer Marketing Sebagai Strategi Pemasaran Digital Era Moderen (Sebuah Studi Literatur). Jurnal Eksekutif, 15(1), 133146.

Kotler, P., \& Keller, K. L. (2016). Marketing Management Global Edition (Vol. 15E). https://doi.org/10.1080/08911760903022556

Kusumastuti, A., Khoiron, M., \& Achmadi, A. (2020). Metode Penelitian Kuantitatif Google Books.

2020. https://www.google.co.id/books/edition/Metode_Penelitian_Kuantitatif/Zw8REAAAQB $\mathrm{AJ} ? \mathrm{hl}=\mathrm{id} \& \mathrm{gbpv}=1 \& \mathrm{kptab}=$ overview

Nurdin, I., \& Hartati, S. (2019). METODOLOGI PENELITIAN SOSIAL - Google Books. 2019.

https://www.google.co.id/books/edition/METODOLOGI_PENELITIAN_SOSIAL/tretD wAAQBAJ?hl=id\&gbpv=1\&dq=pengertian+populasi\&pg=PA91\&printsec=frontcover

Priansa, D. J. (2017). K. P. T. P. E. M. S. B. P. S. (2017). Komunikasi Pemasaran Terpadu Pada Era Media Sosial.

Rahardjo, S., \& Gudnanto. (2013). Pemahaman Individu Teknik Nontes - Google Books. 2013.

https://www.google.co.id/books/edition/Pemahaman_Individu_Teknik_Nontes/GhZND wAAQBAJ?hl=id\&gbpv=1\&dq=pengertian+kuesioner\&pg=PA94\&printsec=frontcover

Rangkuti, F. (2009). (2009). Strategi promosi yang kreatif. Gramedia Pustaka Utama.

Siyoto, S., \& Ali, M. (2015). DASAR METODOLOGI PENELITIAN - Google Books. 2015. https://www.google.co.id/books/edition/DASAR_METODOLOGI_PENELITIAN/QPh FDwAAQBAJ?hl=id \&gbpv=1\&dq=pengertian+populasi\&printsec=frontcover

Smuda, C. (2018). Influencer Marketing. A Measurement Instrument to Determine the $\begin{array}{llll}\text { Credibility... } & - & \text { Google } & \text { Books. }\end{array}$ https://www.google.co.id/books/edition/Influencer_Marketing_A_Measurement_Instr/6 V5yDwAAQBAJ?hl=id\&gbpv=1\&dq=influencer+marketing \&printsec=frontcover

Aaker, D. (2013). Advertising's Role In Building Strong Brands.

Ansori, M. (2020). Metode Penelitian Kuantitatif Edisi 2 - Google Books. https://www.google.co.id/books/edition/Metode_Penelitian_Kuantitatif_Edisi_2/rKbJD wAAQBAJ?hl=id \&gbpv=1\&dq=pengertian+skala+likert \&printsec=frontcover

Brown, D., \& Fiorella, S. (2013). Influence Marketing - Google Books. 2013. https://www.google.co.id/books/edition/Influence_Marketing/xRt-

kC6wo34C?hl=id\&gbpv=1\&dq=influencer+marketing\&pg=PT48\&printsec=frontcover

Ghozali, I. (2013). Aplikasi Analisis Multivariate dengan Program IBM SPSS 21 Update PLS Regresi. Badan Penerbit Universitas Diponegoro.

Hariyanti, N. T., \& Wirapraja, A. (2018). Pengaruh Influencer Marketing Sebagai Strategi Pemasaran Digital Era Moderen (Sebuah Studi Literatur). Jurnal Eksekutif, 15(1), 133146. 


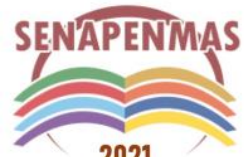

2021
Seminar Nasional Hasil Penelitian dan Pengabdian Kepada Masyarakat 2021

Pengembangan Ekonomi Bangsa Melalui Inovasi Digital Hasil Penelitian dan Pengabdian Kepada Masyarakat Jakarta, 21 Oktober 2021

Kotler, P., \& Keller, K. L. (2016). Marketing Management Global Edition (Vol. 15E). https://doi.org/10.1080/08911760903022556

Kusumastuti, A., Khoiron, M., \& Achmadi, A. (2020). Metode Penelitian Kuantitatif Google Books.

2020. https://www.google.co.id/books/edition/Metode_Penelitian_Kuantitatif/Zw8REAAAQB AJ?hl=id\&gbpv=1\&kptab=overview

Nurdin, I., \& Hartati, S. (2019). METODOLOGI PENELITIAN SOSIAL - Google Books. 2019.

https://www.google.co.id/books/edition/METODOLOGI_PENELITIAN_SOSIAL/tretD wAAQBAJ?hl=id\&gbpv=1\&dq=pengertian+populasi\&pg=PA91\&printsec $=$ frontcover

Priansa, D. J. (2017). K. P. T. P. E. M. S. B. P. S. (2017). Komunikasi Pemasaran Terpadu Pada Era Media Sosial.

Rahardjo, S., \& Gudnanto. (2013). Pemahaman Individu Teknik Nontes - Google Books. 2013.

https://www.google.co.id/books/edition/Pemahaman_Individu_Teknik_Nontes/GhZND wAAQBAJ?hl=id\&gbpv=1\&dq=pengertian+kuesioner\&pg=PA94\&printsec=frontcover

Rangkuti, F. (2009). Strategi promosi yang kreatif. Gramedia Pustaka Utama.

Siyoto, S., \& Ali, M. (2015). DASAR METODOLOGI PENELITIAN - Google Books. 2015. https://www.google.co.id/books/edition/DASAR_METODOLOGI_PENELITIAN/QPh FDwAAQBAJ?hl=id \&gbpv=1\&dq=pengertian+populasi\&printsec=frontcover

Smuda, C. (2018). Influencer Marketing. A Measurement Instrument to Determine the $\begin{array}{llll}\text { Credibility... } & - & \text { Google } & \text { Books. }\end{array}$ https://www.google.co.id/books/edition/Influencer_Marketing_A_Measurement_Instr/6 V5yDwAAQBAJ ?hl=id\&gbpv=1\&dq=influencer+marketing \&printsec=frontcover 
Seminar Nasional Hasil Penelitian dan Pengabdian Kepada Masyarakat 2021

Pengembangan Ekonomi Bangsa Melalui Inovasi Digital Hasil Penelitian dan

Pengabdian Kepada Masyarakat

Jakarta, 21 Oktober 2021

(halaman kosong) 